\title{
Koyunculuk İşletmelerinin Sosyo-Ekonomik Durumu; Hakkâri İli Örneği
}

\author{
Köksal KARADAȘ \\ Iğdır Üniversitesi Ziraat Fakültesi Tarım Ekonomisi Bölümü, Iğdır \\ (Sorumlu yazar email: kkaradas2002@gmail.com)
}

Geliş Tarihi :20.04.2017

Kabul Tarihi :05.10.2017

\begin{abstract}
ÖZET : Hakkâri ili koyunculuk ișletmelerinin demografik özellikleri, koyunculuk faaliyeti ile ilgili problemleri ve çözüm önerilerinin belirlenmesi amacıyla yapılan çalışmada Basit Tesadüfi Örnekleme Yöntemine göre belirlenen 113 işletme ile anket yapılmıştır. Çalışma sonucunda üreticilerin yaş ortalamasının 49 ve koyunculuk tecrübesinin 27 yıl olduğu belirlenmiştir. İşletme başına nüfus ortalaması 10,21 olup bu değer Erkek İş Birimi (EİB) cinsinden ise 6,51 dir. Üreticilerin \%9,7'si okuryazar olmayıp $\% 64,7$ 'si ilkokul mezunudur. İşletme başına ortalama 14 da'lık alanda buğday, yonca ve bostan üretimi yapılmaktadır. Faaliyet dönemi sonunda her ișletmede ortalama 96 koyun, 86 kuzu ve 6 koç olup bunların her birinin değeri 416 TL, 309 TL ve 958 TL olup toplam değerleri ise 74.336 TL dir. Üreticiler herhangi bir tarımsal örgüte üye olmayıp bunların \%15,9'unun ortalama 8.819 TL dönem sonu borcu bulunmaktadır. Borç kaynağı akraba ve diğer șahıslardır. İșletmelerde koyun sütü satıșı bulunmamakla birlikte elde edilen süt yağ, yoğurt, peynir ve ayrana dönüştürülerek aracılar vasıtası ile pazarlanmaktadır. Girdi fiyatlarının yüksek olması, sulama sorunu ve yem bitkileri üretiminin yetersiz olması en önemli üretici sorunlardır. Bölge koyunculuk işletmelerinin sorunlarının çözümü için yem bitkileri üretiminin ve girdi desteğinin artırılması, sulama sorunun çözülmesi, sınır güvenliğinin sağlanarak kaçak et ve canlı hayvan girişinin önlenmesi ile bölgeye yönelik küçükbaş hayvancılık politikalarının oluşturulması önerilebilir.
\end{abstract}

Anahtar Kelimeler: Demografik Özellikler, Koyunculuk, Hakkâri, Üretici Sorunları

\section{Socio-Economic Conditions of Sheep Farms: The Case of Hakkari Province}

\begin{abstract}
This study aims to determine demographic characteristics, problems related to sheep breeding and make recommendations for solution of these problems in sheep farms located in Hakkâri province. For this aim, a questionnaire was applied to 113 sheep farms in Hakkâri selected according to simple random sampling method. Data from the questionnaire shows that average age of the farmers is 49 while the average experience in animal breeding is 27 years. Average population of the farms in terms of Male Work Unit (MWU) is 6,51. Grain, barley and vegetables are produced on an average land area of 14 da. per farm. Each farm owns an average of 96 sheep, 86 lambs and 6 rams at the end of the activity season and respective values of these stocks are $416 \mathrm{TL}, 309 \mathrm{TL}$ and $958 \mathrm{TL}$. Average total stock value at the end of season is 74.336 TL.Stockbreeders are not registered with any agricultural organization and 15,9\% of breeders have an average of 8.819TL of debt at the end of the season. Debtors are relatives and other real persons. Farms do not sell sheep's milk, however, milk, butter, yogurt, cheese and ayran are produced in the farms and marketed through middlemen. High input prices, inadequacy of water for both animals and irrigation and and problems in production of feedstuff are the most important factors that have a negative impact on sheepbreeding. In order to improve sheepbreeding in the region, inputs and feedstuff to sheep farms must be subsidized, water problems in villages and pastures must be solved, illegal entry of meat and live animals must be stopped by increasing border security and sheepbreeding policies, tailored for the region, must be formulated.
\end{abstract}

Keywords: Demographic Characteristics, Sheepbreeding, Hakkari, Producer Problems.

\section{GİRİs}

Koyun farklı şartlara kolayca uyum sağlayabilmekte, düşük kalitedeki meralardan yeterince faydalanabilmekte, az bir emek ile bakımı ve beslemesi yapılabilmekte olup (Paksoy ve Özçelik, 2008; Anonim, 2012), üreticiler koyunculuk faaliyetini düşük bir sermaye ile yapabilmektedir (Semerci ve Çelik, 2016). Koyunculuk faaliyeti tarım sektöründe çalışanlara istihdam olanağı sağlamakta olup koyunculuktan elde edilen ürünler insan beslenmesinde kullanılmasına ilave olarak giyim sektörü, ilaç ve kozmetik sanayi gibi alanlarda değerlendirilmektedirler (Günaydın, 2009; Tamer, 2014). Ayrıca koyun sütü kuzuların beslenmesinde kullanılmakta ve peynir, yağ, yoğurt, ayran vb. yapımında kullanılmaktadır (Sezenler vd., 2016). Koyun yetiştiriciliği için uygun tarımsal yapı ile doğal ve ekonomik şartlara sahip olan Türkiye'de koyunculuk geleneksel olarak yapılmaktadır
(Akçapınar vd., 2002). Dünya koyun varlığının \%2,6's1 Türkiye'de bulunurken (Anonim, 2014a), Türkiye'de üretilen sütün $\% 6,3$ 'ü koyunlardan elde edilmektedir (Anonim, 2015). 2014 yilında Türkiye'de 30.694 ton koyun peyniri, 26.400 ton koyun tereyağı, 98.978 ton koyun eti üretilmiştir (Anonim, 2014b). 1991 yılı Türkiye koyun varlığ 40.432 .340 baș olup bu say1 2016 y1lında 30.983 .933 başa gerilemiştir. Türkiye koyun varlığının \%93'ünü düşük süt verimine sahip yerli urklar oluştururken (Anonim, 2016a), yerli 1rkların \% $40 \quad 1 \mathrm{n} 1$ ise Akkaraman ırkı oluşturmaktadır (Ertuğrul vd., 2009). Türkiye koyun varlığının \%1,9’u (592.460 baş) 37.34 kuzey enlem ile 43.43 doğu boylamlarının kesiştiği bölgede bulunan ve $1.720 \mathrm{~m}$ yükseklikteki Hakkâri'de bulunmaktadır (Anonim, 2016b). Hakkâri'de bulunan ve koyun yetiştiriciliği yapan üreticilerin daha fazla kazanç sağlamaları için 
koyunculuğun sorunlarının belirlenmesi ve çözülmesi gerekmektedir. $\mathrm{Bu}$ çalışma, Hakkâri ilinde koyunculuk işletmelerinin sorunlarının ve bu sorunların çözümüne yönelik önerilerin belirlenmesi amacıyla yapılmıştır.

\section{MATERYAL ve METOT}

\section{Materyal}

Araştırmanın ana materyalini Hakkâri İlinde koyun yetiştiriciliği yapan işletmelerle yapılan anketlerden sağlanan veriler oluşturmaktadır. Ayrıca konu hakkında daha önce yapılmış çeşitli ulusal ve uluslararası araştırma makaleleri ve raporlar ile çeşitli istatistik kurumlarının verileri araştırmanın ikincil veri kaynaklarını oluşturmaktadır.
Metot

Örnek Büyüklüğünün Belirlenmesinde Uygulanan Metot:Örnekleme yöntemi kullanılarak bir popülasyon hakkında daha ayrıntılı, daha ucuz ve daha çabuk bir şekilde veriler elde edilmektedir (Çiçek ve Erkan, 1996; Yamane, 2010). Araştırma popülasyonunu 2014 yılında Hakkâri ilinde koyun üretiminin $\% 25,46$ 'sının (149050 baş) gerçekleştirildiği Merkez İlçe (Anonim, 2014b) Gayeli Örnekleme Yöntemi ile belirlendikten sonra anket yapılacak işletme sayısının tespitinde Hakkâri İl Gıda Tarım ve Hayvancılık Müdürlüğü ÇKS' ye kayıtlı koyun üreticileri dikkate alınmıştır.

Koyun varlığı dikkate alınarak popülâsyonu temsil edecek işletme sayısı;

$$
\mathrm{n}=\frac{\mathrm{N} \mathrm{S} \mathrm{t}^{2}}{(\mathrm{~N}-1) \mathrm{d}^{2}+\mathrm{S}^{2} \mathrm{t}^{2}} \text { formulü kullanılarak elde edilmiştir (Çiçek ve Erkan, 1996)). }
$$

$\mathrm{n}$ : Popülasyonu temsil edecek işletme sayısını,

$\mathrm{N}$ : Popülâsyondaki toplam işletme sayısını (992),

S: Popülâsyonun standart sapması (70.8),

t : \% 90 güven sınırlarında cetvel değeri (1.65)

$\mathrm{D}=\mathrm{kabul}$ edilebilir hata payı (Popülâsyon ortalamasının \% 10’u: 10.3)

$$
\mathrm{n}=\frac{992 \times 70.8^{2} \times 1,65^{2}}{(992-1) 10.3^{2}+70.8^{2} \times 1.65^{2}}=112,8
$$

Anket yapılacak işletme sayısı hesaplandıktan sonra ankete tabi tutulacak işletmelerin tespitinde tesadüfî sayılar çizelgesi kullanılmıştır.
Erkek İș Birimi (EİB) ve Büyükbaș Hayvan Birimi (BBHB) Hesaplanmasında Kullanılan Metot:

Erkek İş Birimini Hesaplamada Kullanılan Katsayılar Çizelge 1. de verilmiştir (Karadaş, 2000).

İşletmelerde bulunan toplam hayvanların BBHB cinsinden hesaplanmasında kullanılan formül Çizelge 2' de verilmiştir (Aktaş, 2009).

Çizelge 1. Erkek iş birimini hesaplamada kullanılan katsayılar

\begin{tabular}{lll}
\hline Yaş & $\begin{array}{l}\text { Cinsiyet } \\
\text { Erkek }\end{array}$ & Kadın \\
\hline $0-6$ & 0,00 & 0,00 \\
$7-14$ & 0,50 & 0,50 \\
$15-49$ & 1,00 & 0,75 \\
$50-64$ & 0,75 & 0,50 \\
$65 \mathrm{ve}+$ & 0,50 & 0,50 \\
\hline
\end{tabular}

Çizelge 2. BBHB'nin hesaplanmasında kullanılan katsayıları

\begin{tabular}{llll}
\hline Cinsi & BBHB & Cinsi & BBHB \\
\hline İnek & 1,00 & Toklu & 0,08 \\
Boğa & 1,40 & Kuzu & 0,05 \\
Buzaği & 0,16 & Teke & 0,12 \\
Dana & 0,50 & Keçi & 0,10 \\
Düve & 0,70 & Çepiç & 0,08 \\
Koç & 0,12 & Oğlak & 0,05 \\
Koyun & 0,10 & Kümes hayv. & 0,004 \\
\hline
\end{tabular}


Anket Formlarının Hazırlanmasında ve İstatistiksel Analizde Uygulanan Metot:

2014 yılı tarımsal üretim dönemini kapsayan anketlerde işletmecinin yaşı, eğitim düzeyi, işletme nüfusu ve iş gücü durumu, işletmelerin arazi varlığı, parsel sayısı ve münavebe durumu, işletmelerin küçükbaş hayvan varlığı, üreticilerin borçluluk durumu, koyunculukla ilgili sorunlar ve çözüm önerileri vb. konularla ilgili sorular bulunmaktadır. Yapılan hesaplamalarda EXCEL ve SPSS 21 paket programları kullanılmıştır.

\section{BULGULAR VE TARTISMA}

\section{İşletmelerin Nüfus ve İşgücü Düzeyi}

Hakkâri ili koyunculuk işletmelerinin sosyo ekonomik yapıları değerlendirilirken ilk olarak demografik özellikler dikkate alınmıştır. Üreticilerin yaşları 26-76 arasında değişmekle birlikte ortalama 49'dur. İşgücü nüfusun sosyal ve ekonomik niteliklerini belirttiğinden işletmeler açısından önemlidir ve hesaplanması gerekmektedir (Peker ve Ayyıldız, 1996). Çizelge 3'te görüleceği gibi koyun yetiştiriciliği yapan işletmelerde işgücü miktarı Erkek İş Birimi (EİB) olarak 6,51 olup hane halkı sayısı 2 ila 13 arasında değişmekte ortalama 10,21 adet olup bu değer 2011 yılı hane halkı sayısına göre hem Türkiye $(3,8)$ ve hem de Hakkâri ili ortalama hane halkı sayısından $(7,2)$ daha fazladır (Anonim, 2011). Ortalama değer olarak işletmelerde kız çocuğu sayısı 2,4 , erkek çocuğu sayısı 2,7 ve ortalama çocuk sayısı 5,1 adettir. Üreticilerin iş tecrübeleri 6 ile 55 yıl arasında değişmekte ve ortalama 27 yıl olarak belirlenmiştir.

Çizelge 3. İncelenen işletmelerde nüfusun yaş ve cinsiyete göre dağılışı ve EİB

\begin{tabular}{lccc}
\hline Yaş & Ortalama Birey sayısı & Katsayı & EİB \\
\hline $0-6$ & 0,38 & 0,00 & 0,00 \\
7-14 Kadın-Erkek & 1,83 & 0,50 & 0,91 \\
15-49 Kadın & 2,05 & 0,75 & 1,54 \\
15-49 Erkek & 1,93 & 1,00 & 1,93 \\
50-64 Kadın & 3,35 & 0,50 & 1,67 \\
50-64 Erkek & 0,54 & 0,75 & 0,40 \\
65 + Kadın-Erkek & 0,13 & 0,50 & 0,06 \\
\hline Toplam & 10,21 & & 6,51 \\
\hline
\end{tabular}

\section{İşletmecilerin Eğitim Durumu}

Koyun yetiştiren üreticilerin $\% 9,7$ 'si okuma yazma bilmemekte, \%64,7'si ise ilkokul düzeyinde eğitime sahiptir (Çizelge 4.) Koyunculuk işletmelerinin demografik özellikleri ile ilgili önceki çalışmalarda Aktürk vd., (2005) koyunculuk işletmelerinde ortalama nüfusun 4,4 ve işletme başına işgücünün 3,21 EİB olduğunu, Sezgin (2006) göçer aile reislerinin ortalama yaşının 44 ve göçer ailelerin $\%$ 47,7'sinin 1.000-3.000 baş koyuna sahip olduklarını, Dayan (2007) koyun yetiştiricilerinin; yaş ortalamalarının 35-50, eğitim durumunun \% 59,15'nin ilkokul mezunu, aile bireyleri sayısının ortalama 8 kişi, arazi varlığının ise ortalama 137 da olduğunu, Ceyhan vd., (2015) Şahinli (2011) koyunculuk işletmelerinde bir çiftçi ailesinin ortalama nüfusu 3,97 kişi ve ortalama işletme arazisi genişliği 137,95 da olduğunu, koyun yetiştiren işletme sahiplerinin büyük bir kısmının $(\% 68,8)$ ilkokul mezunu olduğu, koyunculuk yapma süresinin ortalama 25,7 yıl olduğu belirtmiştir.

Çizelge 4. İşletmecilerin eğitim durumu

\begin{tabular}{lcc}
\hline Eğitim Durumu & $\mathbf{N}$ & $\mathbf{\%}$ \\
\hline Okuryazar değil & 11 & 9,7 \\
Okuryazar (diploma yok) & 32 & 28,3 \\
İlkokul mezunu & 41 & 36,4 \\
Ortaokul mezunu & 12 & 10,6 \\
Lise Mezunu & 17 & 15,0 \\
\hline Toplam & 113 & 100 \\
\hline
\end{tabular}

\section{Yabancı İsgücü Kullanım Durumu}

İşletmelerin \%90,3'ünde en az bir yabanc1 işçi çalışmakta olup bu işçilerin yaş ortalaması ise 32'dir. Koyunculuk işletmelerinde çobanlık ve sağım işlerinde ortalama 153,63 gün çalışan yabancı işçiler ortalama olarak dönem sonunda $463,63 \mathrm{TL}$ değerinde $48,88 \mathrm{~kg}$ peynir ile yevmiye 86,36 TL/gün olmak üzere 14.768,18 TL nakit para almışlardır (Çizelge 5.). 
Çizelge 5. İşletmelerdeki yabancı işgücü durumu

\begin{tabular}{lrrr}
\hline Değişkenler & Minimum & Maksimum & Ortalama \\
\hline İşinin yaş1 & 25 & 40 & 31,90 \\
İşletmede çalıștı̆ı süre (gün) & 150 & 160 & 153,63 \\
Aldığı ayni ürün (peynir) (kg) & 15 & 110 & 48,88 \\
Aldı̆̆ı ayni ürün (peynir) değeri (TL) & 150 & 1100 & 463,63 \\
Nakdi ücret (TL) & 12.750 & 17.100 & $14.768,18$ \\
Yevmiye (TL) & 80 & 95 & 86,36 \\
\hline
\end{tabular}

\section{Arazi Kullanım Durumu}

İşletmeler bitkisel üretimlerinin tamamını kıraç arazide yapmakta olup bu arazinin dekarını 70 TL'den kiralamakta ve 4.190 TL'den ise satmaktadır. $\mathrm{Bu}$ kıraç arazilerde 106 işletmede 1,8 parsel ve 6 dekarlık alanda buğday üretimi, 94 işletmede 1 parselde 2 dekarlık alanda bostan ve 103 işletmede
1,4 parsel 6 dekarlık alanda yonca üretimi yapılmaktadır ve ayrıca her işletmenin bitkisel üretim alanı ortalama 14 dekardır. Buradan işletmelerin hayvansal üretim için yeterli ürün üretecek kadar araziye sahip olmadıkları anlaşılmaktadır (Çizelge 6.).

Çizelge 6. İşletmelerin arazi kullanım durumları

\begin{tabular}{lcccccc}
\hline Ürünler & $\begin{array}{c}\text { İşletme } \\
\text { sayısı }\end{array}$ & $\mathbf{( \% )}$ & Parsel sayısı & $\begin{array}{c}\text { Minimum } \\
(\mathbf{d a})\end{array}$ & $\begin{array}{c}\text { Maksimum } \\
(\mathbf{d a})\end{array}$ & $\begin{array}{c}\text { Ortalama } \\
(\mathbf{d a})\end{array}$ \\
\hline Buğday & 106 & 93,80 & 1,8 & 1 & 18 & 6 \\
Yonca & 103 & 91,15 & 1,4 & 1 & 21 & 6 \\
Bostan & 94 & 83,18 & 1 & 1 & 6 & 2 \\
\hline
\end{tabular}

\section{Hayvan Varlığı}

İşletmelerde her biri $416 \mathrm{TL}$, toplam değeri 40.929 TL olan 96 adet koyun, her biri 309 TL, toplam değeri 27.481 TL olan 86 adet kuzu ve her biri $958 \mathrm{TL}$, toplam değeri $5.926 \mathrm{TL}$ olan 6 adet koç bulunmaktadır. Her işletmede BBHB cinsinden ortalama 14,5 hayvan varlığı hesaplanmıştır (Çizelge 7.). Üreticilerin tamamı koyunculuk faaliyetinden elde ettikleri ürünleri aracılar vasıtası ile pazarlamaktadırlar.

Çizelge 7. İşletmelerin hayvan varlığ

\begin{tabular}{lrc}
\hline Cinsi & Adet & BBHB \\
\hline Koyun & 96 & 9,6 \\
Kuzu & 86 & 4.3 \\
Koç & 6 & 0,6 \\
\hline Toplam & 170 & 14,5 \\
\hline
\end{tabular}

\section{İşletmelerin Borçluluk Durumu}

Üreticilerin koyunculuk faaliyeti süresince borçluluk durumları, borcun alınış amacı, vadesi ve kaynağ çizelge 8'de verilmiştir. Üreticilerin \%41.6's1 dönem başında borçlu iken \%58.4'ünün borcu bulunmamakta olup dönem başı ortalama borç miktarı 6.628 TL dir. Dönem içerisinde 21 üretici ortalama $9480 \mathrm{TL}$ borç alırken 24 üretici ortalama 8.615 TL dönem içerisinde ödeme yapmıştır. Dönem sonu itibarı ile 55 üreticinin $(\% 48,7)$ ortalama 5 ay vadeli 10.868 TL borcu bulunmaktadır.

Çizelge 8. İşletmelerin borçluluk durumları

\begin{tabular}{llllllll}
\hline & $\begin{array}{l}\text { Borçlu Sayısı } \\
\text { (Adet) }\end{array}$ & \multicolumn{2}{l}{$\begin{array}{l}\text { Borçsuz Sayısı } \\
\text { (Adet) }\end{array}$} & En Az (TL) & $\begin{array}{l}\text { En Fazla } \\
\text { (TL) }\end{array}$ & $\begin{array}{l}\text { Ortalama } \\
\text { (TL) }\end{array}$ \\
\cline { 2 - 8 } & Sayı & \% & Sayı & \% & & & \\
\hline Dönem Başı & 47 & 41,6 & 66 & 58,4 & 500 & 24.000 & 6.628 \\
Dönem İçi Alınan & 21 & 18,6 & 45 & 39,8 & 1.000 & 23.000 & 9.480 \\
$\begin{array}{l}\text { Dönem İçi Bir Kısmını } \\
\text { Ödeyen }\end{array}$ & 24 & 21,2 & & & 2.000 & 22.000 & 8.615 \\
$\begin{array}{l}\text { Dönem Sonu } \\
\text { Vade }\end{array}$ & 55 & 48,7 & 58 & 51,3 & 1.000 & 18.000 & 10.868 \\
\hline
\end{tabular}


Üreticilerin borçlanma nedenleri içinde en fazla payı \%45,1 ile üretim masrafları alırken en az borçlanma nedeni ise \%1,8 hayvan alımı olarak belirlenmiştir (Çizelge 9.). Üreticiler koyun tedarikini işletme içerisinde ürettikleri kuzulardan sağlamaları nedeni ile koyun alım masrafi oldukça düşük çıkmıştır.

Çizelge 9. İşletmecilerin borç alma nedenleri

\begin{tabular}{lrr}
\hline Borç Alma Nedeni & Sayı & $\%$ \\
\hline Üretim Masrafları & 51 & 45,1 \\
Aileni Zorunlu Gıda Maddelerinin Karşılanması & 14 & 12,4 \\
Ağıl Yapımı & 3 & 2,7 \\
Hayvan Alımı & 2 & 1,8 \\
Borç Almayan & 43 & 38,0 \\
\hline Toplam & 113 & 100 \\
\hline
\end{tabular}

\section{Koyunculuk Faaliyeti Sorunları ve Çözüm Önerileri}

Koyun yetiştiriciliği yapan üreticilerin koyunculukla ilgili sorunları belirlenerek Çizelge 10. da verilmiştir. Üreticilere koyun yetiştiriciliği yaparken en çok karşılaştıkları problemler sorulmuş ve üreticilerin tamamı yem fiyatlarının yüksek olduğunu, sulama problemi bulunduğunu ve yem bitkileri üretimi sırsında problemlerle karşılaşıldığını belirtmişlerdir. Diğer önemli sorunlar arasında yetiştiricilik konusunda teknik eğitim yetersizliği, örgütlenmedeki sorunlar ve verilen girdi desteğinin yetersiz olduğu ifade edilmiştir. Problemlerin önemlilik sıralamasında en son sırayı ise Devletin her yıl hayvancılığa yönelik değişken bir politika izlemesi almaktadır (Çizelge 10.).

Çizelge 10. Koyunculuk faaliyeti sorunları

\begin{tabular}{|c|c|c|}
\hline Sorunlar & $\begin{array}{l}\text { Cevap } \\
\text { Sayısı }\end{array}$ & $(\%)$ \\
\hline $\begin{array}{l}\text { Yem fiyatlarının yüksek olması, sulama sorunu ve yem bitkileri üretiminde karşılaşılan } \\
\text { sorunlar. }\end{array}$ & 113 & 14,16 \\
\hline $\begin{array}{l}\text { Üniversitenin yeni kurulmuş olması ve üreticilere yeterince birebir eğitim verememesi } \\
\text { ve üreticiye ulaşamaması. }\end{array}$ & 106 & 13,28 \\
\hline $\begin{array}{l}\text { Profesyonel hayvan beslemesini ve modern işletme için gereken kurallar bölge insanı } \\
\text { tarafinda bilinmiyor olması. }\end{array}$ & 91 & 11,40 \\
\hline $\begin{array}{l}\text { İşletmelerin girdi temininden ürünlerinin pazarlanmasına kadar olan örgütleme ilgili } \\
\text { sorunlar. }\end{array}$ & 90 & 11,28 \\
\hline $\begin{array}{l}\text { Hayvansal üretime verilen destek ve hibelerin doğru kanallara aktarılmaması ve verilen } \\
\text { bu desteklerin yarar ve zararlarının analiz edilmemesi. }\end{array}$ & 86 & 10,78 \\
\hline $\begin{array}{l}\text { Pazarlama ile ilgili sorunlar.(ithal ürünler, yerli et ve süt ürünlerinin değerinin düşük } \\
\text { olması, gelirlerin büyük bir kısmının aracılara gitmesi) }\end{array}$ & 82 & 10,28 \\
\hline Mera ıslahının yapılmaması, aşırı otlanma, meranın korunmaması. & 80 & 10,02 \\
\hline $\begin{array}{l}\text { Sürü sağlığı konusunda yetiştiricinin bilinçli olmaması ve hayvan hastalandıktan sonra } \\
\text { müdahale edilmesi. }\end{array}$ & 72 & 9,02 \\
\hline $\begin{array}{l}\text { Barınak alanları (büyüklük } \mathrm{m} 2 \text { olarak) ve havalandırma yerleri ile ilgili önemli } \\
\text { problemler. }\end{array}$ & 44 & 5,51 \\
\hline Devletin hayvancılığa yönelik her sene değişken bir politika uygulaması. & 34 & 4,26 \\
\hline Toplam cevap sayıs & 798 & 100 \\
\hline
\end{tabular}

Bölge koyunculuk sorunlarını belirten işletmeciler bu sorunların çözüm önerilerini ifade ederken öncelik sıralaması yapılmış ve Çizelge 11 'de bu öneriler verilmiştir. Buna göre en fazla tekrarlanan çözüm önerisi bölgede model işletmelerin yaygınlaştırılması ve böylece yatırımcıların kafalarındaki soruların giderilmesi olarak belirlenmiştir. Diğer çözüm önerileri et ithalatının durdurulması, kültür ırkı hayvan alımının kolaylaştırılması, pazarlama sorununun çözümüne yönelik önlemlerin alınması, hayvan barınak yapımının teknik ve ekonomik bakımdan 
desteklenmesi, üreticilere koyun yetiştiriciliği konusunda eğitim verilmesi, küçükbaş hayvan üreticilerinin örgütlenmesi sağlanmalı, bölgeye yönelik küçükbaş hayvancılık politikalarının oluşturulması ve model işletmelerin oluşturulmasıdır. Geeta vd. (1999) koyunculukta y1llık faaliyet sonuçları ve brüt kârlarının pozitif olduğunu, Alçiçek ve Yurtman (2009) Koyun yetiştiriciliğinde başarının büyük ölçüde koyun başına büyütülen kuzu yüzdesi ve pazara sunulan kuzu miktarı ile ölçüldüğünü bildirmiştir.

Deniz (2009) koyun başına düşen verimin yükseltilmesi bakımından; yem bitkileri ekim alanlarının arttırılması, yem miktarı ve kalitesinin uygun olması, bakım ve besleme koşullarının iyileştirilmesi gerektiğini, Karaca vd. (2009) koyun sayısındaki sayısal azalmanın nedenleri arasında işletmelerin küçük, dağınık ve örgütsüz oluşunu, Çağlıyan ve Durmuş (2010) Diyarbakır Havzası'nda küçükbaş hayvancılığın gerek güvensizlik ortamı gerekse de ekonomik sorunlardan dolayı son dönemlerde giderek azalmasına dikkat çekmişler ve 15 yıllık dönemde küçükbaş hayvan sayısında \%50'lik bir azalma meydana geldiğini, Yılmaz vd. (2014) koyunculuğun Ekonomik açıdan bakıldığında yüksek bir gelir getirmesi yanı sıra, sosyolojik olarak da yüzyıllardır sürdürülen geleneksel bir yaşam tarzı olduğunu göçer koyunculuğun birçok sorunu da beraberinde getirdiğini ve bu nedenle bu üretim sistemi için devlet eliyle ciddi politikaların devreye sokulması gerektiğini, Ayvazoğlu Demir vd. (2015) koyunculuk işletmelerinin pek çoğunun küçük ölçekli aile işletmesi tarzında oluşu, pazar koşullarına karşı üreticinin pazar ve fiyat garantisinin olmaması nedeniyle, verilen destek ve teşviklere rağmen işletmelerin sermaye artırımına gidemediğini ve rasyonelleşmediğini belirtmiştir.

Çizelge 11. Koyunculuk faaliyetinin geliştirilmesi için üreticilerin yaptıkları öneriler

\begin{tabular}{|c|c|c|}
\hline Çözüm Önerileri & $\begin{array}{l}\text { Cevap } \\
\text { Sayısı }\end{array}$ & $(\%)$ \\
\hline $\begin{array}{l}\begin{array}{l}\text { Bölgede model işletmeler yaygınlaştırılarak yatırımcıların } \\
\text { giderilmelidir. }\end{array}\end{array}$ & 109 & 12,18 \\
\hline Et ithalatının durdurulması, et fiyatlarında üretici yönünden olumlu gelişmelere yol açabilir. & 106 & 11,84 \\
\hline $\begin{array}{l}\text { Hayvansal üretimde kültür ırkı hayvan varlığının artırılması ve yaşam koşulları iyileştirerek, } \\
\text { verim de arttırılabilir. Irk ıslahı ve modernizasyon birlikte yapılmalıdır. }\end{array}$ & 93 & 10,39 \\
\hline $\begin{array}{l}\text { Yapılan üretimi batı illerine pazarlamak hedeflenmelidir. Pazarlamayı yapabilmek için } \\
\text { kaliteli ve yüksek oranda üretimi gerçekleştirmek gerekir. }\end{array}$ & 89 & 9,94 \\
\hline $\begin{array}{l}\text { Devlet eliyle daha modern barınakların yapılmalı ve yetiştiriciler bu konuda eğitilmelidir. } \\
\text { Barınaklarla ilgili her yöreye uygun hayvan barınak modeli geliştirilmelidir. }\end{array}$ & 83 & 9,27 \\
\hline $\begin{array}{l}\text { Gıda, Tarım ve Hayvancılık Bakanlığı meraları ılah etmeye ve korumaya yönelik } \\
\text { çalışmaları artırmalıdır. Otlatma teknikleri ile kullanılan meralardaki hayvanlarda çok ciddi } \\
\text { verimler alınabilir. }\end{array}$ & 81 & 9,05 \\
\hline Koyun Üreticilerinin örgütlenmesi sağlanmalı. & 80 & 8,94 \\
\hline $\begin{array}{l}\text { Bölgeye yönelik küçükbaş hayvancılık politikası belirlenmeli buna yönelik çalışmalar } \\
\text { yapılmalıdır. }\end{array}$ & 71 & 7,93 \\
\hline $\begin{array}{l}\text { Islah konusunda çalışmalar yapılmalı, üreticilere yeterli derecede veteriner hizmeti verilmeli } \\
\text { ve devlet desteğinden yararlanılmak için bilgilendirilmelidirler. }\end{array}$ & 75 & 8,38 \\
\hline $\begin{array}{l}\text { Hayvanların yaylaya çıkmadan aşılanması, il içerisinde hayvan hastalıklarının yayılmasını } \\
\text { büyük ölçüde engellenmiş olacaktır. }\end{array}$ & 62 & 6,93 \\
\hline $\begin{array}{l}\text { Yem bitkileri üretimi teşvik edilerek, üreticiler bu konuda eğitilmeli ve silaj makineleri } \\
\text { alımına destek verilmelidir. }\end{array}$ & 46 & 5,14 \\
\hline Toplam & 895 & 100 \\
\hline
\end{tabular}

\section{SONUÇ ve ÖNERILER}

Hakkâri İlinde 113 adet koyun üreticisi ile yapılan anketler değerlendirilmiş ve üreticilerin ortalama yaşları 49 olup her işletmede 6,51 EİB ve 10,21 adet hane halkı bulunmakla birlikte üreticilerin iş tecrübesi 27 yıldır. İşletmecilerin \%64,9'u ilkokul düzeyinde eğitime sahiptir. 14 dekarlık alanda üreticiler buğday, arpa ve bostan üretimi yapmaktadırlar. Her işletmede 170 adet küçükbaş hayvan bulunurken bu hayvanların BBHB cinsinden miktarı 14,5 tir. Dönem başında üreticilerin \%41,6's1 ortalama 6.628 TL borçlu iken dönem sonunda $\% 48,7$ si 10.828 TL borçlu durumdadırlar. Üreticilerin en önemli sorunları yem fiyatlarının yüksek olması, sulama sorunu, yem bitkileri üretimindeki problemlerdir. Yetiştirme tekniği ve örgütlenme yetersizliği, destekleme, pazarlama ve barınak yetersizlikler diğer problemler arasındadır. 
Bölge koyunculuk faaliyetinin geliştirilmesi için koyunculuk işletmelerine verilen girdi desteğinin arttırılması, koyun yetiştiriciliği ve yem bitkileri üretimi konusunda teknik eğitim verilmesi gereklidir. Bölgede modern barınakların kurulmasının sağlanması için gerekli tedbirler alınarak kaçak hayvan ve et girişinin önüne geçilmelidir. Koyun yetiştiriciliği için gerekli girdilerinin daha uygun şartlarda sağlanacağı ve ürünlerin daha kolay pazarlanacağı kooperatifler kurulması üretici problemlerinin çözümü açısından önemlidir.

\section{KAYNAKLAR}

Akçapınar, H., Ünal, N., Atasoy, F., Özbeyaz, C. ve M., 2002. Karayaka ve Bafra (Sakız $\times$ Karayaka G1) Koyunlarının Lalahan Hayvancılık Araştırma Enstitüsü Şartlarına Uyum Kabiliyeti. Lalahan Hayvancılık Araştırma Enstitüsü Derg. $42,11-24$.

Aktaş, A., 2009. Konya İli Karapınar İlçesi Koyunculuk İşletmelerinin Ekonomik Analizi. Yüksek Lisans Tezi, Selçuk Üniv. Fen Bilimleri Enstitüsü. Konya.

Aktürk, D., Savran, F., Hakyemez, H., Daş, G. ve Savaş, T., 2005. Gökçeada'da Ekstansif Koşullarda Hayvancilık Yapan İsletmelerin Sosyo-Ekonomik Durumu, Tarım Bilimleri Derg. 11, 229-235.

Alçiçek, A. ve Yurtman, Y., 2009. Entansif Koyunculukta Beslenme. Uludağ Üniv. Ziraat Fak. Derg. 23, 1-13.

Anonim, 2011. TUiK. Türkiye İstatistik Kurumu. Nüfus ve Konut Araștırmaları.

http://www.tuik.gov.tr/PreHaberBultenleri.do?id=15843 (15 Subat 2017)

Anonim, 2012. Küçükbaş Hayvancılık Çalıştay Raporu. Doğu Anadolu Kalkınma Ajansi. 8-9 Haziran 2012. Hakkari. 167 s.

Anonim, 2014a. FAOSTAT. Food and Agricultural Organization of the United Nations. http://www.fao.org/faostat/en/\#data/QA (15 Şubat 2017)

Anonim, 2014b. TUIK. Türkiye İstatistik Kurumu. Hayvancıllk İstatistikleri.

https://biruni.tuik.gov.tr/hayvancilikapp/hayvancilik.zul (09.02.2017)

Anonim, 2015. Türkiye İstatistik Kurumu. Hayvansal Üretim istatistikleri

http://www.tuik.gov.tr/PreHaberBultenleri.do?id=21822 $\quad(9$ Şubat 2017)

Anonim, 2016a. TUIK. Türkiye İstatistik Kurumu. Hayvancıllk İstatistikleri. http://rapory.tuik.gov.tr/17-02-2017-16:16:0021191502262850069831280502936.html? (5 Mart 2016)

Anonim, 2016b. TUIKK. Türkiye İstatistik Kurumu. Hayvanc1lık İstatistikleri. http://rapory.tuik.gov.tr/20-03-2017-22:20:404388274069747744361519285160.html? (10 Mart 2016)

Ayvazoğlu, Demir., P, Adıgüzel Işık, S., Aydın, E., Yazıcı, K. ve Ayvazoğlu, C., 2015. Ardahan İlinde Koyun Yetiştiriciliğinin Sosyo-Ekonomik Önemi, Van Veteriner Journal, 26, 141-146.
Çağlıyan, A. ve Durmuş, E., 2010. Diyarbakır Havzası ve Yakın Çevresinde Küçükbaş Hayvancılık, Fırat Üniv. Sosyal Bilimler Derg. 20, 29-56.

Ceyhan, A., Şekeroğlu, A., Ünalan, A., Çınar, M., Serbester, U., Akyol, E. ve Yılmaz, E., 2015. Niğde İli Koyunculuk İşletmelerinin Yapısal Özellikleri ve Sorunları Üzerine Bir Araștırma, KSÜ Doğa Bil. Derg, 18, 60-68.

Çiçek, A., Erkan, O., 1996. Tarım Ekonomisinde Araştırma ve Örnekleme Yöntemleri. Gaziosmanpaşa Üniv. Ziraat Fak. Yayınları No:12, Ders Notları Serisi No:6, Tokat.

Dayan, Y. A., 2007. Norduz Koyunu Yetiştiriciliği Yapılan Kimi İşletmelerin Yapısal Özellikleri. Yüzüncü Yıl Üniv. Fen Bilimleri Enstitüsü. Yüksek Lisans Tezi, Van.

Deniz, A., 2009. Hakkari İli Merkez İlçede Koyunculuk Yapan İşletmelerin Ekonomik Analizi. Yüzüncü Yıl Üniv. Fen Bilimleri Enstitüsü. Yüksek Lisans Tezi, Van.

Ertuğrul, M., Dellal, G., Soysal, İ., Elmacı, C., Akın, O., Arat, S., Barıtçı, İ., Pehlivan, E. ve Yılmaz, O., 2009. Türkiye Yerli Koyun Irklarının Korunması. Türkiye Ulusal Koyunculuk Kongresi 12-13 Şubat, İzmir.

Geeta, M., Sunanda, K. and Bhavani, K., 1999. Karnataka Sheep Farmers, Indian Journal of Small Ruminants, 5, 82-84.

Günaydın, G., 2009. Koyun Yetiştiriciliğinin Ekonomi Politiği, Uludağ Üniv. Ziraat Fak. Derg. 23, 15-32.

Karaca, O., Arık, İ. Z., Biçer, O., Cemal, İ., Yılmaz, O. ve Ulutaş, Z., 2009. Türkiye Koyunculuğunda Üretim Sistemleri ve Stratejik Öneriler. Türkiye Ulusal Koyunculuk Kongresi, 12-13 Şubat, İzmir.

Karadaş, K., 2000. Erzurum İlinde Patates Üretim Ekonomisi. Atatürk Üniv. Fen Bilimleri Enstitüsü. Yüksek Lisans Tezi, Erzurum.

Paksoy, M. ve Özçelik, A., 2008. Kahramanmaraş İlinde Süt Üretimine Yönelik Keçi Yetiştiriciliğine Yer Veren Tarım İşletmelerinin Ekonomik Analizi. Ankara Tarım Bilimleri Derg. 14, 420-427.

Peker, K. ve Ayyıldız, T., 1996. Pasinler İlçesi Tarım İșletmelerinde Atıl İsgücünün Tespiti ve Bu İsgücünü Değerlendirme İmkanları. Tr. J. Of Ariculture and Forestry, 20, 23-190.

Semerci, A. ve Çelik, A. D., 2016. Türkiye'de Küçükbaş Hayvan Yetiştiriciliğinin Genel Durumu. Mustafa Kemal Üniv. Ziraat Fak. Derg. 21, 182-196.

Sezenler, T., Ceyhan, A., Yüksel, M. A., Koncagül, S., Soysal, D. ve Yildırır, M., 2016. Influence of Year, Parity and Birth Type on Milk Yield and Milk Components of Bandirma Sheep (German Black Head Mutton x Kıvırcık). Journal of Agricultural Sciences, 22, 89-98.

Sezgin, Y., 2006. Bitlis İlinde Göçer Ailelerin Küçükbaş Hayvancılık Faaliyetleri. Yüzüncü Yıl Üniv. Fen Bilimleri Enstitüsü. Yüksek Lisans Tezi, Van.

Şahinli, M. A., 2011. Konya İlinde Koyunculuk Faaliyetine Yer Veren Tarım İşletmelerinin Ekonomik Analizi ve Koyunculuk Faaliyetinde Etkili Olan Unsurlarn Saptanması. Ankara Üniv. Fen Bilimleri Enstitüsü. Doktora Tezi, Ankara

Tamer, B., 2014. Yozgat Merkez İlçede Koyunculuk Yapan İșletmelerin Sosyo-Ekonomik Yapısı ve Üretim Maliyetlerinin Araştırılması. Erciyes Üniv. Sağlık Bilimleri Enstitüsü. Yüksek Lisans Tezi, Kayseri.

Yamane, T., 2010. Temel Örnekleme Yöntemleri. Literatür Yayıncilı. İstanbul.

Yılmaz, O., Karaca, O., İnce, D., Cemal, İ., Yaralı, E., Varol, M. ve Sevim, S., 2014. Batı Anadolu Göçer Koyunculuğu ve Islah Planlamalarındaki Rolü, Tekirdağ Ziraat Fak. Derg. $11,89-97$ 